\title{
Program One Pesantren - One Product in the Perspective of Social Entrepreneurship
}

\author{
Mahfud \\ Sekolah Tinggi Ilmu Bahasa Asing (STIBA) Invada Cirebon, Indonesias \\ mahfud.invada@gmail.com
}

\begin{abstract}
One Pesantren-One product is a social entrepreneurship program that has the aim of developing an Islamic boarding school-based economy. Participants of one pesantren one product will be assisted through entrepreneurship training, capital, packaging design and creating an online platform. The aim of the research is to explain the program from a social entrepreneurship perspective. This study used a qualitative approach with a case study method at the Pesantren At-Taqwa Digitalpreneurship. Data collection was carried out by observation, in-depth interviews and literature study. The results showed that the one pesantren-one product program was based on 4 concepts, namely social value, Innovation, civil society and economic activity so that the implementation was in line with the local wisdom of the pesantren itself.
\end{abstract}

Keywords

one pesantren-one product; social enterpreneurship; pesantren at-taqua

\section{Introduction}

Social enterprises are productive structures that have an imprint of social benefit and, in this sense, it can be affirmed that they are alternative forms of companies within a neoliberal capitalism, which houses organizations oriented to profit, capital accumulation and enrichment of few people, contributing to the polarization between the city and the countryside. On the contrary, in social enterprises, cooperative work and decision-making are promoted in a consensual or democratic way: the partners are simultaneously the workers as they determine how and in what way the benefits will be applied and the benefits will be distributed. In addition, they use management techniques that contribute to the sustainability of the Company (Lendechy, 2019).

Walser (2000) observes that the mining situation remains challenging and real sustainable development is not just all about financial flows. As mining should have been the key supporter concerning economic development, is likewise being linked with triggering a number of economic, environmental and social complications that has led several people to question the sustainability of the economic aftermath of mining besides, promoted the resource curse theory. Therefore, the input of mining to sustainable development needs to be measured in relation to economic and technical sustainability, ecological viability and social evenhandedness. In an attempt to accomplish this, governments, mining companies and local communities need to work together on these concerns at diverse phases of the mining project covering the period from exploration, to mine operation, up to post mine cessation (Mansaray 2020).

Social entrepreneurship is defined as a new perspective in the business world, encouraging business actors to create profits to provide real social change, job creation is a concrete form of the concept of social entrepreneurship. Social entrepreneurship has a high responsibility, which has to sacrifice a lot both "money, time, and feelings." Another 
thing that needs to be in the concept of social entrepreneurship is never to give up. If there are a hundred problems, one must have a hundred ideas to solve them (Utomo, 2015).

Social entrepreneurship is a process that involves the use and combination of resources innovatively to open up opportunities to accelerate social change and/or meet social needs (Mustanir, 2019) so that it can be concluded that social entrepreneurship aims to solve social problems in society and not solely to looking for profits, which are the characteristics of social entrepreneurship, including the creation of social values, Innovation, civil society, and the existence of economic activity (Hulgard, 2010).

Social entrepreneurship plays a vital role in poverty reduction efforts. Social business manifestations further reinforce that entrepreneurship is an economic lever for society to improve the economy and increase income. Social entrepreneurship encourages economic development, although a long-term path to the poverty alleviation agenda can be realized (Mursidi, 2020).

According to Rudito (2020) emphasizes that social entrepreneurship initiates social changes that occur in society. As initiators, they have social Innovation and the capacity for development to have a social impact through social entrepreneurship. Social entrepreneurship as a dynamic process is created and managed by individuals or teams who try to take advantage of social Innovation with an entrepreneurial mindset to create new social values in the market and society (Yudha, 2018).

Social entrepreneurship sees problems as opportunities to form new business models that are beneficial to empowering local communities. Furthermore, Setyanto (2017) explained that a social entrepreneur is someone who understands social problems and uses his entrepreneurial skills to make social change, especially in the fields of welfare, education and healthcare. If business entrepreneurs measure the success of their financial performance (profit or income), then social entrepreneur success is measured by the benefits felt by the community.

Social entrepreneurship or social entrepreneurship is different from the concept of a business entrepreneur, even though both encourage the creation of economic activities. Mansur (2017) illustrates that the concept of business entrepreneurs is more oriented towards ownership of assets and wealth that rests on personal individuals.

Meanwhile, social entrepreneurs, if they have wealth from economic activities, then this wealth is used to help the community. Astawa (2017) said that social entrepreneurship has the goal of achieving profit, where the goal of profit makes social entrepreneurship closely related to the concept of opportunity cost and profit maximization. Social entrepreneurship carries out social activities by earning a profit and then distributes it as an effort to create social value.

Entrepreneurship development is carried out by developing quality entrepreneurial entrepreneurs, both in terms of knowledge and skills or abilities and mentally in the hope of creating independence in doing business and doing business (Firdaus, 2014). This view is very important when the business involved is related to community social activities and positively impacts the environment. Conventional business actors have similarities with social entrepreneurs, except that social entrepreneurs are an asset and the main element of social entrepreneurship in society and a determinant of the growth of an area in developing community-based entrepreneurship.

Entering the era of the industrial revolution 4.0 requires all business actors, stakeholders to innovate so that they can have an impact on the surrounding environment. The West Java Government is here to answer problems with the One Pesantren-One Product (OPOP) Program, this program aims to create the independence of the people through the students, the community and the Islamic Boarding School itself, to be able to 
be economically, socially independent and also to spur skill development, production technology, distribution, marketing through an innovative and strategic approach from the West Java Provincial Government and the KUKM Office of West Java Province, ensuring that all Islamic boarding schools in West Java can gain access to government programs in the sector of economic empowerment, technology and production that are efficient, precise and modern in today's digital era. All pesantren selected through selection will later be given an integrated coaching program. Their economic competitiveness will also be enhanced and assisted in the process of business development, synergize in potential business networks until they succeed in becoming an independent Islamic boarding school.

In line with the above program, Saragih's research (2017) explains that every business program related to community engagement efforts is called social entrepreneurship. This essence must be in line with the vision and mission of social entrepreneurship itself.

The purpose of this study is to explain the one pesantren-one product program from a social entrepreneurship perspective so that in the future, this research can be useful for the West Java provincial government and the whole community.

\section{Research Methods}

This research uses a case study method where the main explanation focuses on the analysis results and discussion of theories that are by the research problem. The case study taken is the main subject of the discussion of this research, namely the one pesantren-one product program at the At-Taqwa digitalpreneur Islamic boarding school from an entrepreneurial perspective. Case study research is research conducted to find out more deeply the problem of one or more independent variables (Sugiyono, 2017).

The research data were obtained from secondary data and from some literature that was considered supportive in line with social entrepreneurship research. Data analysis was carried out by triangulating the data obtained, looking for the relationship and then making conclusions and according to the research topic.

\section{Results and Discussion}

The research results on the one pesantren-one product program at Pesantren AtTaqwa from the perspective of social entrepreneurship provide the following picture.

\subsection{Social Value}

One Pesantren-One Product is here to solve economic problems in West Java. In the process of implementing the At-Taqwa Islamic Boarding School has implemented several social values, the Pesantren seeks to provide anti-usury values to the surrounding community so that all people who take part in this program are free from debt bondage loan sharks, according to Hilbig (2009) social value orientation in the economy is to create new passion in society to participate in activities according to the vision and mission of the movement.

Pesantren At-Taqwa Digitalpreneur Sidogiri is able to present solutions to social problems in innovative ways and combines local wisdom and social Innovation by participating in the One Pesantreb-One Product Program to get social entrepreneurship assistance so that it can create several values, visions and missions. Whereas the opinion of Reginalid (2014) explains that there are two characteristics of social entrepreneurship, namely decision making in these social entrepreneurial institutions is not based on capital 
ownership but decisions are issued by each management of these social entrepreneurial institutions as in the cooperative concept, namely the highest position in the management including the distribution of social funds.

\subsection{Innovation}

The application of the concept of Innovation at the At-Taqwa Islamic Boarding School in the One Pesantren-One Product program gave birth to several external programs, the program involved the surrounding community to jointly build a savings and loan cooperative, a sharia-based company and rebuild alumni ties together. Spread this social entrepreneurship movement. In this program, the Government of West Java provides a source of ideas related to the creation of a social media platform to help sell products built by Islamic boarding schools that are managed by the surrounding community.

Another Innovation program is to make a patent name that is registered with the Ministry of Law and Human Rights of the Republic of Indonesia, the purpose of this legality is to gain the trust of the public and strong social capital to jointly build a shariabased social entrepreneurship movement with the one pesantren-one product program.

According to Wahyono (2019) every program that uses digital assistance and has social entrepreneurship values will open opportunities for each product to market various kinds of products through digital media. Before entering the digital era, local product marketing had difficulty marketing it. Therefore, this program was born to help open this access and impact the economy of the surrounding community, especially the At-Taqwa Digitalpreneur Islamic Boarding School.

\subsection{Civil Society}

The Civil Society in the environment around the pesantren provides views and initiatives and community participation in its social structure involving internal and external from the boarding school and related stakeholders regarding the characteristics of social entrepreneurship based on activities born from the thinking of the community itself. These activities are participatory in nature and involve civil society and collaboration between alumni and students. This is in line with Kurniati (2015) opinion that activities initiated by the community and have a participatory nature, especially involving those who are affected by the activities and impacts of social entrepreneurship.

Pondok Pesantren At-Taqwa digitalpreneur Sidogiri Pasuruan has a mission to contribute through civil society how to create a usury-free society and moneylenders based on social entrepreneurship Baldatun by building the spirit of the people's economic movement whose goals are education, economy and social unemployment in the neighborhood around the pesantren.

Based on the results of social entrepreneurship research at the Ay-Taqwa Islamic Boarding School, it shows that social entrepreneurship must be accompanied by social values that create real social benefits for the community and the surrounding environment. Entrepreneurship level indicators consist of four indicators attached to a person or institution which include, (1) social benefits, (2) agents of change), (3) social Innovation, and (4) economic activity (Hulgard 2010). In this study, the level of social entrepreneurship in individuals, so that the assessment is also seen in the individual character inherent every day, especially with the One Pesantren-Ome Product program. Assessment of the level of social entrepreneurship needs to involve people who know the character before and after the program is carried out. 


\subsection{Economic Activity}

Social entrepreneurship at the At-Taqwa Digitalpreneur Islamic Boarding School also provides increased community economic activities since the One Pesantren-One Product mentoring program, the characteristics of the community's economic activities around the Islamic Boarding School usually rely on rice fields, bamboo handicrafts and become factory workers, but due to social entrepreneurship programs. The community is able to carry out economic activities in local institutions and experience various kinds of increased income in the family.

According to Cahlid (2009) and Marini (2015) the positive impact of economic activity is to provide economic improvement and help the family economy for members who take part in the social entrepreneurship program, how many benefits are obtained in accordance with the initial agreement because the essence of social entrepreneurship is solving social problems in the community and contribute to good thinking.

\section{Conclusion}

The One Pesantren-One Product program at Pesantren At-Taqwa Digitalpreneur has successfully implemented in accordance with the essence of social entrepreneurship. Each mentoring program provided continues to carry out the values of local wisdom owned by the pesantren, has the spirit of eradicating the loan shark/usury mafia, and provides Innovation in terms of the formation of internal institutions, external with civil society and provide a positive impact in terms of economic activities that provide increased income for the surrounding community.

\section{References}

Astawa, I. P. (2017). Studi Kasus Kewirausahaan Sosial Di Bali Dalam Pendekatan Konsepsual. Jurnal Bisnis dan Kewirausahaan, 12(1 Maret), 12.Chalid, P. (2009). Sosiologi Ekonomi.

Diandra, D. (2019, August). Program Pengembangan Kewirausahaan Untuk Menciptakan Pelaku Usaha Sosial Yang Kompetitif. In Prosiding Industrial Research Workshop and National Seminar (Vol. 10, No. 1, pp. 1340-1347).

Firdaus, N. (2014). Pengentasan kemiskinan melalui pendekatan kewirausahaan sosial. Jurnal ekonomi dan Pembangunan, 22(1), 55-67.

Hilbig, B. E., \& Zettler, I. (2009). Pillars of cooperation: Honesty-Humility, social value orientations, and economic behavior. Journal of Research in Personality, 43(3), 516519.

Hulgard, Lars. 2010. Discourses of Social Entrepreneurship-Variation of The Same Theme? EMES European Research Network.

Kurniati, E. D. (2015). Kewirausahaan industri. Deepublish.

Marini, I. A. K., \& Ningsih, N. S. K. (2015). Ragam aktivitas ekonomi wanita nelayan terhadap peningkatan pendapatan rumah tangga nelayan Di Kota Mataram. Jurnal Ganeç Swara, 9(1), 53-59.

Efendi, M. (2017). Pengelolaan zakat produktif berwawasan kewirausahaan sosial dalam pengentasan kemiskinan di Indonesia. Al-Ahkam Jurnal Ilmu Syari'ah Dan Hukum, 2(1).

Lendechy, H.M.V. and Villagómez, I.T. (2019). Rural Women Who Undertake and Empower Themselves: Comparative Analysis in Communities in Mexico. Budapest International Research and Critics Institute-Journal (BIRCI-Journal). P. 20-30. 
Mansaray, H.E. (2020). Corporate Social Responsibility and Sustainable Development: A Case Study of Multinational Mining Companies in Sierra Leone. Budapest International Research and Critics Institute-Journal (BIRCI-Journal). P. 644-656.

Mursidi, A., Marhayani, D. A., Zulfahita, S., Susanto, H., Setyowati, R., \& WAHYUNI, R. (2020). KEWIRAUSAHAAN SOSIAL. Penerbit Lakeisha.

Mustanir, A. (2019). Pemberdayaan masyarakat kewirausahaan.

Reginald, A. R., \& Mawardi, I. (2014). Kewirausahaan Sosial Pada Pondok Pesantren Sidogiri Pasuruan. Jurnal Ekonomi Syariah Teori dan Terapan, 1(5).

Rudito, B. kewirausahaan sosial. Kementerian Sosial

Saragih, R. (2017). Membangun usaha kreatif, inovatif dan bermanfaat melalui penerapan kewirausahaan sosial. Jurnal Kewirausahaan, 3(2), 26-34.

Sugiyono, F. X. (2017). Neraca pembayaran: Konsep, Metodologi dan penerapan (Vol. 4). Pusat Pendidikan Dan Studi Kebanksentralan (PPSK) Bank Indonesia.

Sutowo, I. R. I. (2020). Komunikasi partisipatif dalam pengembangan kewirausahaan sosial di pandeglang, banten. Expose: Jurnal Ilmu Komunikasi, 3(1), 21-43.

Setyanto P. Santosa, Peran Sosial Entrepreneurship Dalam Pembangunan,makalah yang dipaparkan dalam acara dialog Membangun Sinergisitas Bangsa Menuju Indonesia Yang Inovatif, Inventif dan Kompetitif,Himpunan IESP FE-Universtas Brawijaya, Malang, 14 Mei 2017, hlm. 1

Utomo, H. (2015). Menumbuhkan minat kewirausahaan sosial. Among Makarti, 7(2).

Wahyono, E., Kolopaking, L. M., Sumarti, T., \& Hubeis, A. V. S. (2019). Jaringan Digital dan Pengembangan Kewirausahaan Sosial Buruh Migran Perempuan.

Walser G (2000) Economic impact of world mining. World Bank Group Mining Department, Washington, D.C., United States of America. IAEA-SM-362/7. Retrieved from https://inis.iaea.org/search/search.aspx?orig_q=RN:31054479

Yudha, A. T. R. C., \& Dusturiya, N. (2018). Model Pengembangan Kewirausahaan Sosial Berbasis Mahasiswa pada Lembaga Amil Zakat. el-Qist: Journal of Islamic Economics and Business (JIEB), 8(1), 1618-1637. 